\title{
Can Ethical Business Strategy Influence Consumers' Buying Behavior and Loyalty: Marks and Spencer PLC?
}

\author{
Kamrul Islam \\ University of Essex, Wivenhoe Park, Colchester CO4 3SQ, United Kingdom \\ Tel: 88-0-1716-288646_Ｅ-mail: mrkislam1987@gmail.com
}

Received: April 20, $2016 \quad$ Accepted: May 6, $2016 \quad$ Published: May 19, 2016

doi:10.5296/csbm.v3i1.9471 URL: http://dx.doi.org/10.5296/csbm.v3i1.9471

\begin{abstract}
The project aims to research the impact of ethical business strategy in retail industry. It will primarily focus on one particular aspect of the ethical business strategy, customers' buying behaviour and loyalty issues. For the purpose of this research a leading retailer, Marks and Spencer will be evaluated, the impact of Ethical Business Strategy (known as Plan A) on its 33.6 million consumers' base. Literature review suggests ethical business strategy has an impact on consumers and can enable an organisation to achieve sustainable competitive advantages in the long term. A survey was conducted for consumers of Marks and Spencer Simply Food to establish what impact it had on consumer choice. The findings and analysis of survey data highlighted Plan A fails to influence the majority of the consumer's buying behaviour and loyalty. However it affects between $10 \%$ to $12 \%$ consumers that are viewed as ethical consumers by the Business Analyst. As a result of this research, recommendations have been made for Marks and Spencer. As a student researcher in order to meet time constraints and cost, researcher selected to conduct survey in one department of Marks and Spencer, Marks and Spencer Simply Food. The reader will need to take this limitation into account when reading this report, as the outcomes may have been different if various departments were surveyed.
\end{abstract}

Keywords: Business Strategy, Ethical Business Strategy, Consumers’ Buying Behaviour, Consumers' Loyalty, Corporate Social Responsibilities, Mark and Spencer, Plan A, M\&S Simply Food 


\section{Introduction}

Ethical business strategy and sustainability of business is one of a huge demandable area for research. The goal of business and marketing is to maximize profit lawfully. However, the behaviour in marketplace supposed to be based on ethical approach that ensures the benefits of society (Carrigan et al., 2005).

Ethics is an idea of fairness in practices that are morally right or wrong. Business ethics can be differed from market to market, country to country, however as an impact of globalisation ethical standards and practices are becoming common.

Various organisations express these practices in different ways. Marks and Spencer launched these practices embedded with their business strategy referred to as Plan A. The corporate objectives of plan A is achieving sustainable competitive advantages over competitors and gaining back lost market share along with increasing brand image of trust and respect. The best approach to achieving these are by establishing an image of green and socially responsible business in the marketplace and dominate consumer's buying behaviour to acquire new customers as well as retain existing ones.

\subsection{Background of Plan A and Company Marks and Spencer PLC}

According to M\&S Corporate website, (Marks and Spencer, 2015) UK based retailer Marks and Spencer had about 33.6 million visitors to its stores each week. It offers clothing as well as home products and foods. It is operating 798 stores in UK. Outside the UK, M\&S operates 455 stores across 54 territories. It also provides online shopping facility to consumers. It operates its business according to an ethically driven business model called Plan A. This model is basically embedded with core business strategy. It aims to be the world's most sustainable global retailer by 2020 .

As part of this strategy, M\&S had announced a very public commitment: Plan A with measurable targets, timescales and accountabilities. This strategy is being integrated into all its business functions and strategic business unit and involves suppliers, employees and customers.

According to Plan A 2020 half year update on 2015, (Marks and Spencer, 2014) Plan A was launched in 2007 as 100 commitments. In 2010 Plan A was extended and added 80 more new commitments with 2015 and 2020 deadlines added to the original 100.

The commitment of Plan A includes selling fair trade goods, organic foods, reducing CO2 emission on production, supply chain and in store, using recycling packaging and shopping bags, selling healthy and balanced food, reducing water consumption from foods and flowers, assisting charities, assisting young people into work, providing training to young people, assisting community and engaging supplier and employees to help strengthen livelihoods. They are all categorised into four pillars-inspirations, touch, integrity and innovation.

As a student researcher, it is a broad area to work on entire operation of M\&S, to narrow down the research scope the researcher selected Marks and Spencer Simply Food as the food retailer of UK as the core area. 


\subsection{Rationale of the Study}

According to M\&S Corporate website (2015), M\&S aims to become the world's most sustainable retailer by utilizing Plan A as collective ethical practices. In order to meet the ultimate objectives of Plan A, M\&S ensure they engage their employees, suppliers and customers. Among those commitments of Plan A, some are already have been met and others in working progress. According to M\&S Corporate website, total Plan A 2020 had 100 Commitments, among them M\&S achieved 9 Commitments and rest of 79 are in working progress (Plan A Performance Review, 2014).

It is important to understand how this Plan A is impacting on consumers, as this is an area of achieving sustainable competitive advantages. As M\&S has already met some of the commitments, hence it is the right time to evaluate the Plan A in terms of Customers' views which can be measured by evaluating consumers' buying behaviour and loyalty.

As M\&S has already highlighted three engaging party of Plan A, by selecting one of them-'customers' by the researcher, is a more rationale area to study. Researcher believed the finding of the study will assist M\&S to understand customers' views about Plan A and impact of Plan A on customers' buying behaviour and loyalty issues. Study will help M\&S to develop more initiatives for Plan A to increase consumers' engagement.

Another area of research was to consider the objective of Plan A which was to re-establish popularity as well as brand value. One of the ways to achieve this is by acquiring new customers, retaining the current customers, dominating their buying behaviour by Plan A. Therefore it is essential to know the effectiveness of Plan A on consumers after fulfilling 9 commitments.

\subsection{Research Aim}

The study aims to critically analyse the impact of ethical business strategy on consumers. The researcher decided to study Marks and Spencer Simply Food as food retailer to evaluate the impacts of Plan A (Set Commitments of Ethical Practices) on their customers.

\subsection{Research Objectives}

To meet the aim of research, the researcher will concentrate the following objectives:

- Establish customers’ (M\&S Simply Food) understanding about ethical practices of Marks and Spencer.

- To research the effectiveness of Plan A on consumers' purchasing decisions for Marks and Spencer Simply Food.

- To establish whether these practices make customers loyal to M\&S Simply Food.

- To understand if shoppers concisely take Plan A into account when deciding where to shop.

- To find out if shoppers would shop elsewhere if M\&S withdrew its commitments of Plan A. 


\subsection{Structure of Report}

The report followed a set structure, where the researcher firstly discussed the topic and laid out research objectives. Secondly, the researcher discussed about literature review with the help of theories and common business practices, researcher evaluated the foundation of Plan A and relation with consumers purchasing behaviour and loyalty. In chapter three, researchers discussed research methodology, which deals with research process, research approach, research methods and survey methods. Research methodology assisted researcher to collect data in effective and authentic manner. On the next part, researcher discussed and represented data interpretation, analysis and discussion thereafter. Finally, researcher drew a conclusion with a set of recommendations.

\section{Introduction}

Over this chapter researcher is providing a detailed background of what the study is about. Researcher draws an outline of ethical business practices as embedded business strategy. A detailed account of theories is provided regarding the relationship between ethical business strategy, customer buying behaviour and loyalty. More specifically, the study is about understanding the relationship between ethical business strategy and customers' buying behaviour in retaining loyalty in the context of Marks and Spencer Simply Food as a Food Retailer in UK.

\subsection{Origin of Ethical Practices}

According to Wall et al. (2010, pp. 209-234) origin of the issues and concerns of ethical practices comes from various theories and practices as follows: Corporate agency and responsibility, The Principal-agent Problem, Social Contract Theory, Stakeholder Theory, International Agreement, Industry Specific Agreement, Company Specific Agreement, The role of social activists, National and Global Issues, Business Issues, Environmental Codes and Regulations and Tradable Permits. According to David Grayson (2011, p. 1025), Plan A of M\&S is a co-ordinated and mixture of CSR, environmental issues and all other social responsibilities issues and he expressed this Plan A and its expected ultimate outcome using a flow chart as follows: 


\section{Macrothink}

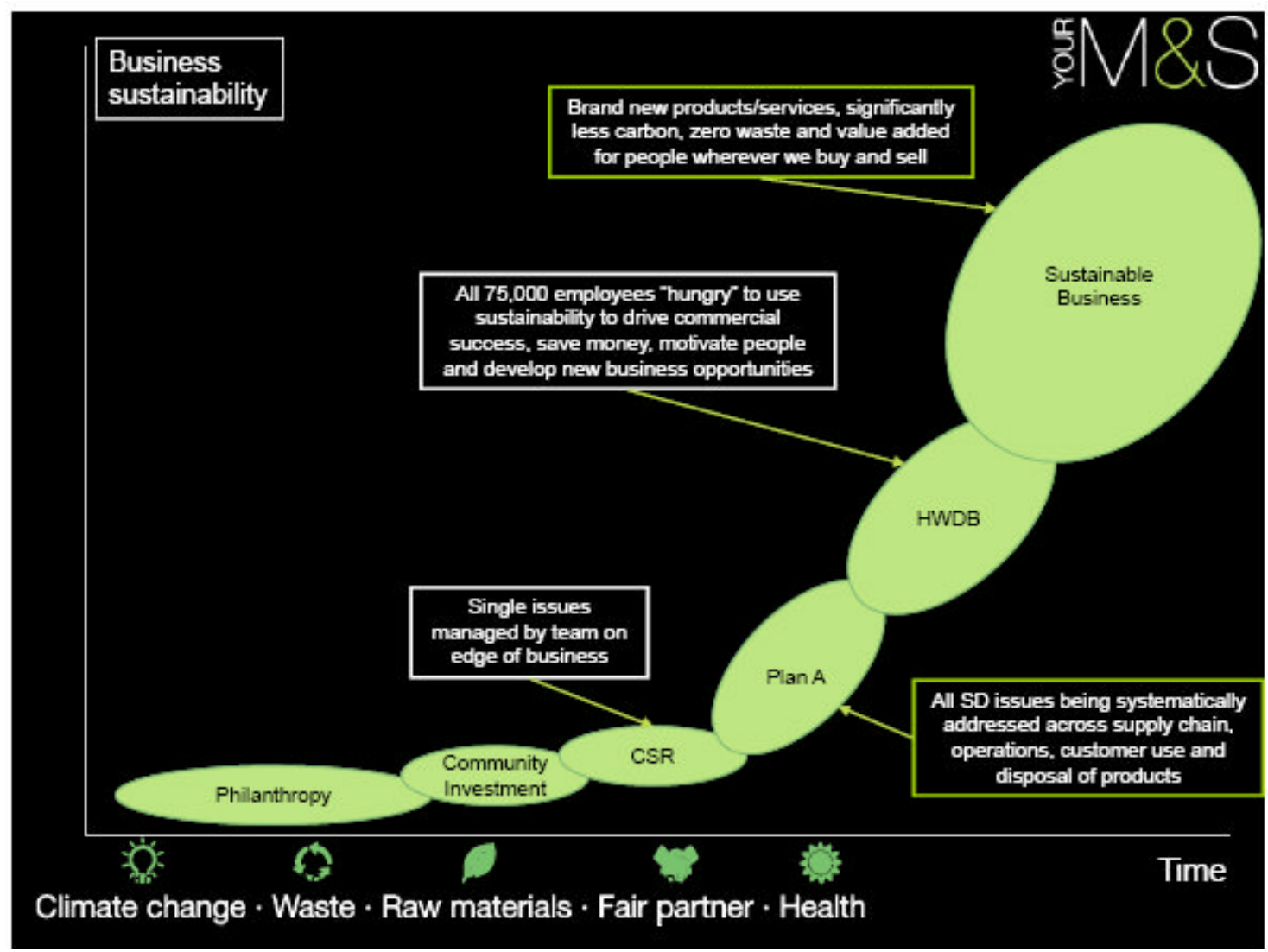

Figure 1. Graphical representation of plan A

Source: Grayson (2011)

\subsection{Necessity of Sustainable Competitive Advantages on Business Strategy}

A type of strategic capabilities, distinctive capabilities are those capabilities, which can assist to create sustainable competitive advantages. In order to sustain in British retail industry, a most competitive industry in the world, M\&S need to achieve some competitive advantages.

Strategic capabilities have four criteria that ensure them achieving sustainable competitive advantages. According to Johnson et al. (2014, pp. 76-80) they are value, rarity, inimitability and organisational support. Strategic capabilities should be valuable to consumers. Value can be measured by monitory or behavioural outcomes. The strategic capabilities should be rare. It should be difficult and expensive to imitate by the competitors. These three criteria can able to bring sustainable competitive advantages only if it has organisational ability to manage those capabilities.

\subsection{Ethical Business Strategy as Sustainable Competitive Advantages}

It is very clear that, in order to establish sustainable business, ethical practices embedded with business strategy can able to meet these four criteria above for Marks and Spencer in UK. After considering these factors, in 2007 CEO Sir Stuart Rose launched a new embedded 


\section{Macrothink}

Case Studies in Business and Management

ISSN 2333-3324

2016, Vol. 3, No. 1

business strategy called Plan A, a collective ethical practice. The objectives of this plan A were to be a sustainable business by achieving competitive advantages over competitors and getting back its earlier brand value, a brand that used to known as a symbol of luxury, trust and respect. Rose discovered Plan A could meet all four criteria of sustainable competitive advantages according to theory. Plan A has value to customers, it is rare and unique, it is very difficult to imitate as it is very expensive to copy and M\&S has sufficient skills and ability to manage Plan A. Researcher worked to find out the outcome of this theory into practice.

\subsection{Elements of Sustainable Business Strategy}

To evaluate the embedded sustainable business strategy, in 2008 Philips, a Dutch lighting and healthcare company published its performance report about its sustainable business strategy where it was found seven elements (Eccles \& Krzus, 2010, p. 116) of sustainable business strategy:

- New business model is required for sustainable development

- This model requires a long term view of implication

- It requires multiple stakeholders’ long term perspective

- New model requires evaluate the stakeholders engagement to understand the expectation

- This model requires to provide value creation to all stakeholders

- There is a risk of adopting new model

- Implementing new model brings real source of competitive advantages.

Plan A meets all those criteria of sustainable business strategy.

\subsection{Relation between Ethical Business Strategy and Customer’s Loyalty}

\subsubsection{Customer's Loyalty}

Loyalty of customers is the key for long-term success in the Retail industry. As a result of globalisation of competition, saturation of markets, and improvement of technology, awareness of consumers has improved and developed a situation where long-term success cannot be achieved through optimised product, price and qualities' (Kuusik, 2007, p. 5). Rootman (2006, p. 2) supports this view by commenting 'high level of competition and ever-changing market conditions is forcing Retail businesses to adopt their business strategies'. As a result of this huge competition companies are tending to design such strategy which can ensure loyalty of consumers.

\subsubsection{Factors Affecting Customers’ Loyalty}

Customer satisfaction, trust, supplier image and commitment are the factors that could affect customers' loyalty. Committed ethical business practices influence all these factors. For example, commitments of Plan A directly influence customers' loyalty.

\subsection{Selling Ethical Behaviour}




\subsubsection{Average Consumers Purchasing Attitude}

According to Chris Arnold (2006, p. 205), consumer can vary their buying behaviour between being passionate about why and what they buy and concern with convenience and price. We all behave this way, depending on circumstances, environment and needs. What you get in the middle is an Average Consumers Purchasing Attitude (ACPA). According to Chris Arnold, the average consumer's purchasing attitude (ACPA) has defined by a line graphs as follows:

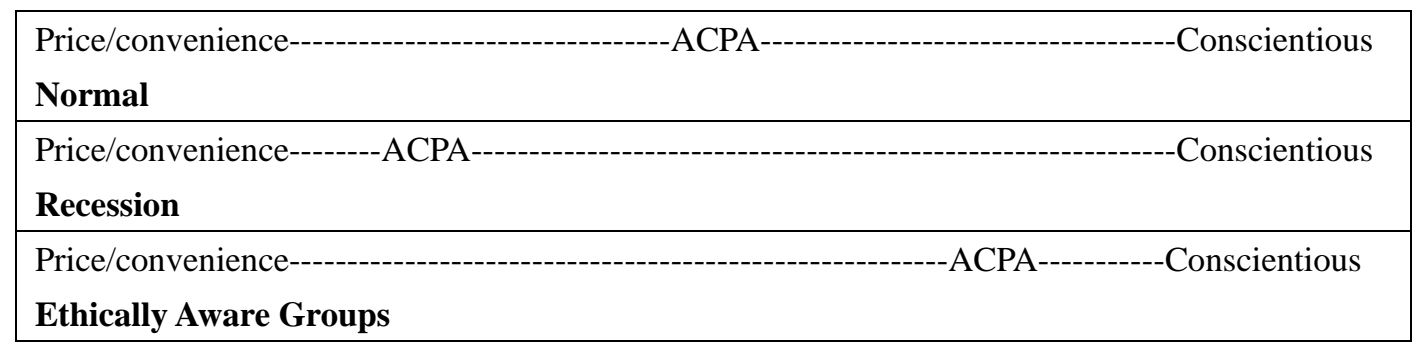

Figure 2. Average consumers’ purchasing attitude

Source: (Arnold, 2009, p. 206)

He exemplified with alcohol industry, he believed as because of ACPA organic ciders, beers and lager sell in a lesser quantities. However, as society becomes more conscious, as it has in some market, the ACPA moves across the line. During recession, in many markets price becomes a key factor and it moves the other way. Supermarket selling bulk discounted lagers encourage people to buy with less concern either taste or ethics.

\subsubsection{A World of Too Much Consumer Choices}

In comparison with the post-war period of late 1940 and early 1950s consumers now have so many choices. As consumers like the idea of choice but they hate it in reality. They want convenience because most of them have little time to think about the options. Ethics has added yet another layer to many factors consumers have to choose from; organic, fair trade, local, lower carbon footprint and so on.

\subsection{The Relationship between Plan A and Customers Derived From History}

During 1990s, as a result of globalisation and increased competition, M\&S lost many of its traditional suppliers and huge amount of market share. It lost its fame and competitive advantages over competitors. As part of its recovery plan set by Stuart Rose in 2007, Plan A was launched which is an embedded ethical business strategy consisted with environmental, social and corporate issues. Plan A became a very public and high profile-primarily to staff and institutional investors, and then to customers and civil society stakeholders. After two and a half years of five years program, Rose and his senior colleagues concluded that there were positive commercial results from their commitments with significant savings and consumers were getting concerned about sustainability very fast. They decided to extend the commitments. The main two reasons M\&S extended the Plan A program were positive 
commercial results and consumers’ engagement (Grayson, 2011).

\subsection{Literature that Closely Related to Topics}

Researcher had reviewed most of the literature exists about these topics on two online libraries -Kaplan Online Library and Albert Sloman Library Online. After all those rigorous two weeks of literature reviews researcher found some related articles. These are discussed as follows:

Arnold carried out a survey across the whole UK (Major cities-Leeds, Manchester, Birmingham, London etc) about ethical practices and customers' impact. The findings of that survey were interesting: people don't understand what a carbon footprints and people do not believe terms like environmentally friendly, they think it was just a greenwash. Someone quoted how come something I was buying yesterday is suddenly saving the planet. However people do get fair trade, organic, recycling, local product, supporting charities as understandable. On average shoppers prepared to pay more for those practices up to $19 \%$ more because they see these ethical values as added values. In this survey there were another findings discovered that regarding the responsibilities for saving the planet, $22 \%$ believed the government should be responsible, $23 \%$ believe big brands, $19 \%$ believed retailers, $26 \%$ believed the consumers which means $42 \%$ believed that business should be responsible. He also found that people understand and believe so many things about ethical practices but they do not act accordingly when it comes into practice (Arnold, 2009, pp. 113-114).

A recent survey by TNS claims that 53\% American consumers would pay more for green products. However 19\% were genuinely concerned with a company's greenness (Arnold, 2009, pp. 113-115).

The Havas Media Global Study reveals that 3\% of shoppers are prepared to pay more for ethical goods, 200 million Americans is now actively purchasing green products. In the UK despite an estimated $£ 200 \mathrm{~m}$ being spent on green marketing, Lippincott found that $70 \%$ of UK consumer could not name a single brand taking a lead on climate change (Arnold, 2009, pp. 113-115).

Ying Fan did research about ethical branding and corporate reputation earlier on 2005 where he found the concept of ethical branding and its link to corporate reputations. Further area to research he suggested was-Does ethical branding affect consumer's purchasing decisions (2005, pp. 241-350).

Researcher found a very close academic research work on Ethical brand and buying behaviour. A survey performed in the USA found that ethical practices is an important consideration during the purchase decision and consumer are willing to pay higher prices for the firm's product (Creyer \& Ross, 1997). However a UK study concludes that although consumer are more sophisticated today, however ethical companies do not necessarily dominate consumers’ buying behavior (Carrigan \& Attalla, 2001, pp. 560-577).

Despite the conflicting finding in those literatures, society today seems to be more concerned about ethical issues compared with 20 years ago. As an increasing number of consumers 
become ethically conscious, they do take ethical issues seriously. These will force companies more ethically accountable nowadays.

These two researches took place before 14-18 years back, now in 2015 the viability of those researches and situation of marketplace has changed in a huge amount for so many reasons though there were clear disagreements on those research findings. Moreover none of the research worked with any specific retail as a case of ethical practices and none of them were about ethical practices as a form of embedded business strategy. So there is a clear gap of literature for further research.

\subsection{Gap of Literature}

Customers express their feedbacks about those ethical strategies through their buying behaviour and being loyal. Top management made the strategy and the result comes from consumers as the competitive advantages for such strategies are achieved mostly by the participation of customers. Therefore, ethical business strategies should be consisted with active participation of the consumers. After performing a wide number of literatures reviews via Kaplan Online Library and Albert Sloman Library Online about this prospective topic, it is clearly justified that-there is not any academic research piece already performed about this topic that is embedded ethical business strategy and influencing ability of that strategy on consumers purchasing behaviour and loyalty for a UK Food retail called Marks and Spencer Simply Food.

\subsection{Summary and Researcher's View}

After going through the literature review the researcher concludes that strategies need to be based on creating competitive advantages and in order to evaluate this sustainable competitive advantages, management should consider the impact of these strategies on customers' buying behaviour and loyalty. British retailers are concentrating on ethical practises and embedding these practices as their business strategy as they believe these will create sustainable competitive advantages for their firms. The ultimate objectives are dominating consumers' buying behaviour and retaining the loyalty. Amongst those retailers, the ironic Marks and Spencer has set itself the ambitious goal to become the world's most sustainable retailer by 2020. It launched its embedded business strategy called Plan A with core business strategy in January 2007. The ultimate aim is to achieve sustainable competitive advantages over competitors and adding values to their value chain, creating financial, social and environmental values for society. Researcher is going to find out some considerable aspects of plan A that M\&S has to think about. The researchable aspects are: customers' understandings about Plan A as collective ethical practices, impact of plan A on customers' buying behaviour and loyalty.

\section{Research Methodology}

Research methodology involves various tools, techniques for data collection and analysing information. With the aid of several research designs, research purpose, research philosophy and analysed data, the researcher will readily be able to establish the impact of Ethical practices on consumers in the UK leading retailer, Marks and Spencer Simply Food. 


\section{Macrothink}

Case Studies in Business and Management

ISSN 2333-3324

2016, Vol. 3, No. 1

\subsection{Method Outline}

In this study, the Researcher selects the positivism research philosophy, descriptive research design and deductive research approach. This enables the Researcher to collect data from primary sources providing an opportunity to apply quantitative analysis. Furthermore, the Researcher selects probability random sampling method to allow the application of quantitative analysis too. While conducting research, the Researcher adopts research ethics to ensure the data collected, is both valid and reliable.

\subsection{Research Onion}

Research onion (Sanders et al., 2012) exemplifies the steps, which must be covered to build a research strategy.

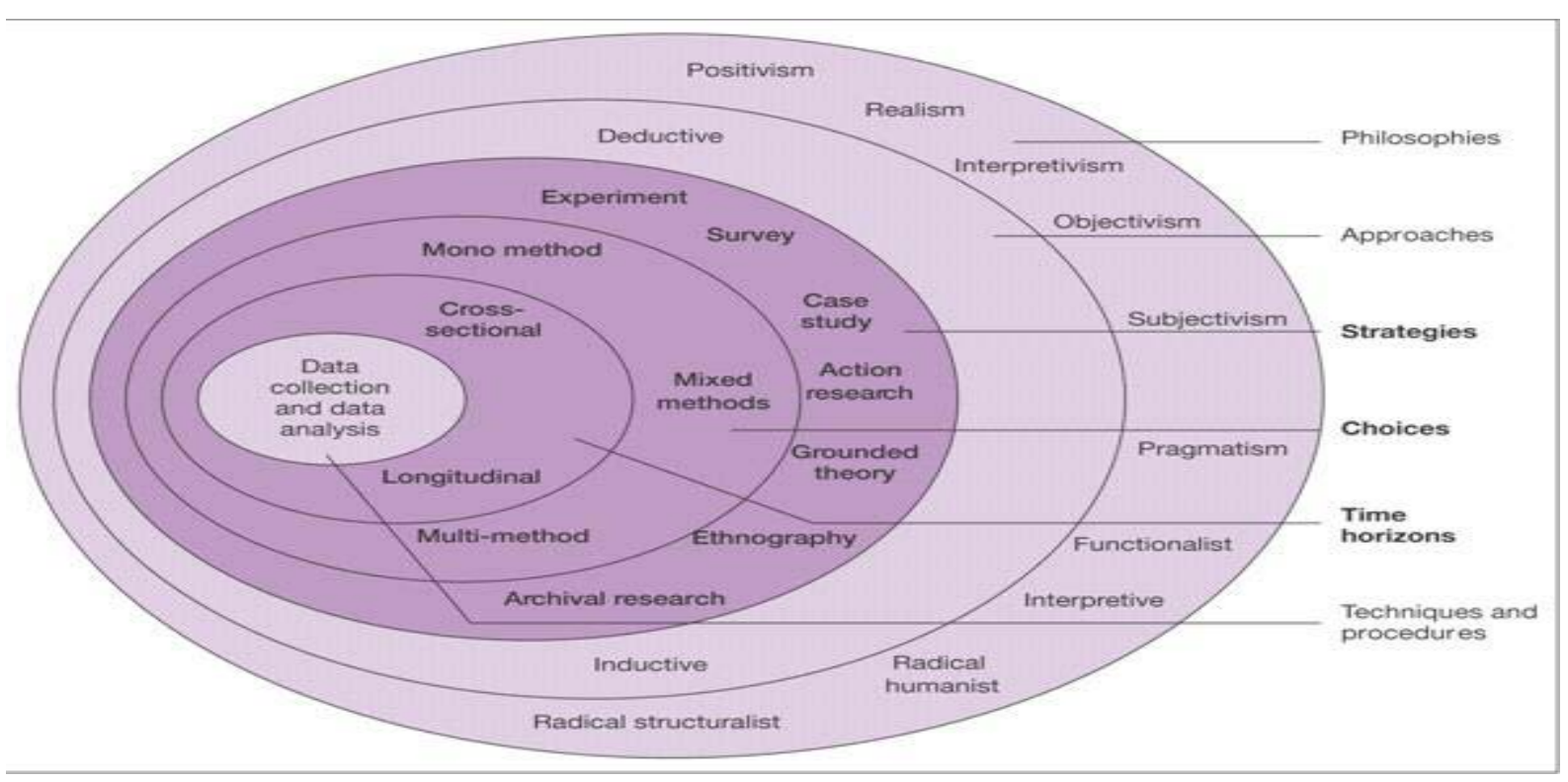

Figure 3. Research onion

Source: Saunders et al., 2012, p. 160

\subsection{Research Philosophy}

Research philosophy can be categorised into three frameworks. They are positivism philosophy, realism philosophy and phenomenology philosophy (Saunders et al., 2012, p. 160). Over here, the researcher used positivism philosophy.

\subsection{Justification for Choosing Positivism Philosophy}

The Researcher adopted the positivism philosophy to derive a conclusion. Researcher is aiming to demonstrate the impact of Ethical Business practices on consumer's buying decision. Therefore, the Researcher must record all possible outcomes. 


\subsection{Research Approach}

There are three types of research approach-inductive, deductive and abductive (Saunders et al., 2012, pp. 145-147). Researcher should apply a framework, where new findings and propositions could be drawn from a particular hypothesis therefore selected "Deductive approach”.

\subsection{Justification for Choosing Deductive Approach}

Deductive approach has been selected by researcher to establish the impact of ethical business practices on consumers buying behaviour. The study highlights new propositions and hypothesises can be drawn here based on existing theories and practices. After studying the existing literature researcher will analyse these critically. Primary data is needed to form the level of effectiveness. Therefore, researcher needs to conduct quantitative analysis of samples. Primary data is needed to form the level of effectiveness. Deductive approach also helps in presenting data in graphical and statistical manner (Saunders et al., 2012, p. 145).

\subsection{Research Design}

Research design helps to understand the way in which respondents are selected and data analysis will be conducted. While conducting an academic or social research three types of designs are used generally. They are quantitative, qualitative and multiple. Researcher here decides to go with multiple one. As researcher collect data by survey as quantitative manner and analyse them as qualitative manner. Nature of research design has three types. Researcher decided to select descriptive studies (Saunders et al., 2012, pp. 160-170).

\subsection{Justification for Choosing Descriptive Research Design}

In this research, Researcher will analyse the impact of Ethical Business Strategy. Hence it provides a clear set of objectives, in addition a description is required for an in depth analysis of the subject. Statistical figures are also necessary so that Researcher can gather valuable and reliable findings. Descriptive design supports cross sectional survey. Moreover, in this case researcher can use a huge range of primary data, as design is descriptive.

\subsection{Data Collection Method}

In this research, Researcher has selected the survey as primary data collection method. Hence primary data is collected by survey questionnaires in this research (Saunders et al., 2012, p. 416).

\subsection{Data Analysis}

Following collection of data from primary sources, Researcher will draw analysis and interpretation of the data. This process helps to transform data into numerical or statistical format. This assists the researcher to describe the nature of the subject and draw constructive conclusions. In this research, data analysis will be applied using both a combination of quantitative and qualitative approaches.

\subsection{Data Analysis Tools}




\section{Macrothink}

Case Studies in Business and Management

ISSN 2333-3324

2016, Vol. 3, No. 1

Researcher uses MS-Excel, spreadsheets for data analysis. Researcher also uses pie charts and bar graphs to present the data systematically. Mean, median and standard deviation are used to analyze the collected data (Saunders et al., 2012, p. 502).

\subsection{Sampling Method and Size}

Researcher uses simple random sampling, a type of probability sampling so that biasness can be avoided (Saunders et al., 2012, pp. 260-262).

According to Marks and Spencer (Marks and Spencer, 2015), it serves about 33.6 million customers every week, among them approximately 18.5 million (From the ratio of 55:45=Food: General Merchandise) served by Marks and Spencer Simply Food. In order to make the sample size more statistically representative, Researcher selects 385 customers of M\&S Simply Food in a random method allowing a margin of error 5\% (Confidence Interval) and confidence level is 95\% (Saunders et al., 2012, p. 265).

\subsection{Procedure of Data Collection}

Following the selection of sample size of 385, the Researcher collected data from Marks and Spencer Simply Food store based in London. Survey was collected though questionnaires which consisted of eight questions. The duration of data collection was approximately 1.5 weeks (Started First week of April, 2015), a target of 40 respondents daily.

\subsection{Ethical Consideration}

Researcher has to follow a set of guidelines to conduct the research in an ethical way. Researcher should present genuine and new primary data. Researcher must not exert pressure on participants to take part in the survey (Saunders et al., 2012, p. 226).

\subsection{Research Limitation}

The research is limited as consumers are reluctant to give full responses to the survey because of timing. The timing of in-store data collection is critical because of the fact that peak and off peak shoppers tend to have a very different socio-economic make-up. Due to time constraints and budget, Researcher selected one single department of Marks and Spencer, Food department instead of clothing, home ware and online, one retail store from this department. Result can be different if conducted with all departments. Also due to time constraints Researcher was unable able to collect any qualitative data, this may have increased the authenticity of the research. 


\subsection{Time table and Gantt-Chart}

Table 1. Time table and Gantt chart for the research Project

\begin{tabular}{|c|c|c|c|c|c|c|c|c|c|c|c|c|}
\hline \multirow[t]{3}{*}{ Action Plan } & \multicolumn{12}{|c|}{ Period In Weeks As Against Each Month } \\
\hline & \multicolumn{4}{|c|}{ March-2015 } & \multicolumn{4}{|c|}{ April-2015 } & \multicolumn{4}{|c|}{ May-2015 } \\
\hline & 1 & 2 & 3 & 4 & 1 & 2 & 3 & 4 & 1 & 2 & 2 & 4 \\
\hline Draft Proposal & & & & & & & & & & & & \\
\hline $\begin{array}{l}\text { Adjustment of Draft } \\
\text { Proposal }\end{array}$ & & & & & & & & & & & & \\
\hline Literature Review & & & & & & & & & & & & \\
\hline $\begin{array}{l}\text { Data Collection and } \\
\text { Interim Report } 1\end{array}$ & & & & & & & & & & & & \\
\hline $\begin{array}{l}\text { Research Process and } \\
\text { Analysis }\end{array}$ & & & & & & & & & & & & \\
\hline Summaries Finding & & & & & & & & & & & & \\
\hline $\begin{array}{l}\text { Final Adjustment and } \\
\text { Interim Report } 2\end{array}$ & & & & & & & & & & & & \\
\hline Submitting final Report & & & & & & & & & & & & \\
\hline
\end{tabular}

\section{Data Interpretation, Finding and Analysis}

Data analysis and interpretation is done based on collected data, found from 385 customers of Marks and Spencer Simply Food Store based on London Bridge, London. In this section researcher has done data interpretation and findings. Researcher uses both quantitative and qualitative analysis to give an insight in the study.

\subsection{Data Analysis}

Question 1: When you buy foods from retailers, what factor you consider most to select a retailer?

\begin{tabular}{|l|l|l|l|}
\hline Options & Total number of respondents & Reponses & Response in \% \\
\hline Availability of store on your location(1) & 385 & 157 & $41 \%$ \\
\hline Brand image of food retailer(2) & 385 & 100 & $26 \%$ \\
\hline The retailer who practices ethics on its strategy(3) & 385 & 48 & $12 \%$ \\
\hline Loyalty with a retailer for a long time(4) & 385 & 73 & $19 \%$ \\
\hline Not sure(5) & 385 & 7 & $2 \%$ \\
\hline
\end{tabular}




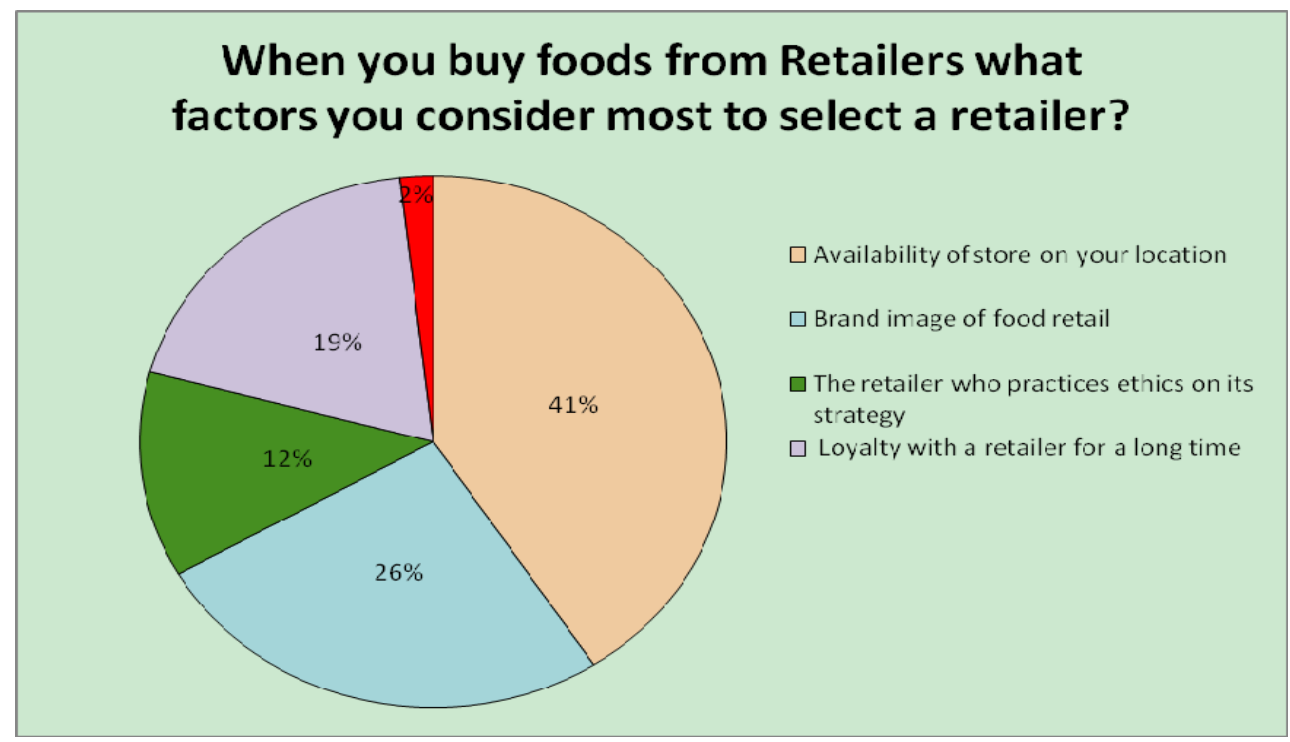

Figure 4. Question 1

\subsubsection{Data Interpretation and Findings: Question 1}

As per the table, it appears that $41 \%$ of the respondents consider availability of store on their location as the main factor to decide from which food retailer they buy their foods. $26 \%$ of customers consider brand image, $12 \%$ consider the retailers who practice ethics, $19 \%$ consider their loyalty with specific retailer and $2 \%$ are not sure.

In the interpretation from the chart, it can be assessed that majority of retail customers buy foods from their nearest store of their location. A small number of customers are indentified, as ethical customers on the retail industry of UK and their percentage is $12 \%$.

Question 2: Why do you shop at M\&S Simply Food rather than other Food retailers?

\begin{tabular}{|l|l|l|l|}
\hline Options & Total number of respondents & Reponses & Response in \% \\
\hline Plan A as collective form of ethical practices(1) & 385 & 41 & $11 \%$ \\
\hline Huge range of quality foods and new innovation(2) & 385 & 168 & $44 \%$ \\
\hline Ironic brand image(3) & 385 & 115 & $30 \%$ \\
\hline Excellent Customer Service(4) & 385 & 50 & $13 \%$ \\
\hline Any other reason(5) & 385 & 11 & $3 \%$ \\
\hline
\end{tabular}




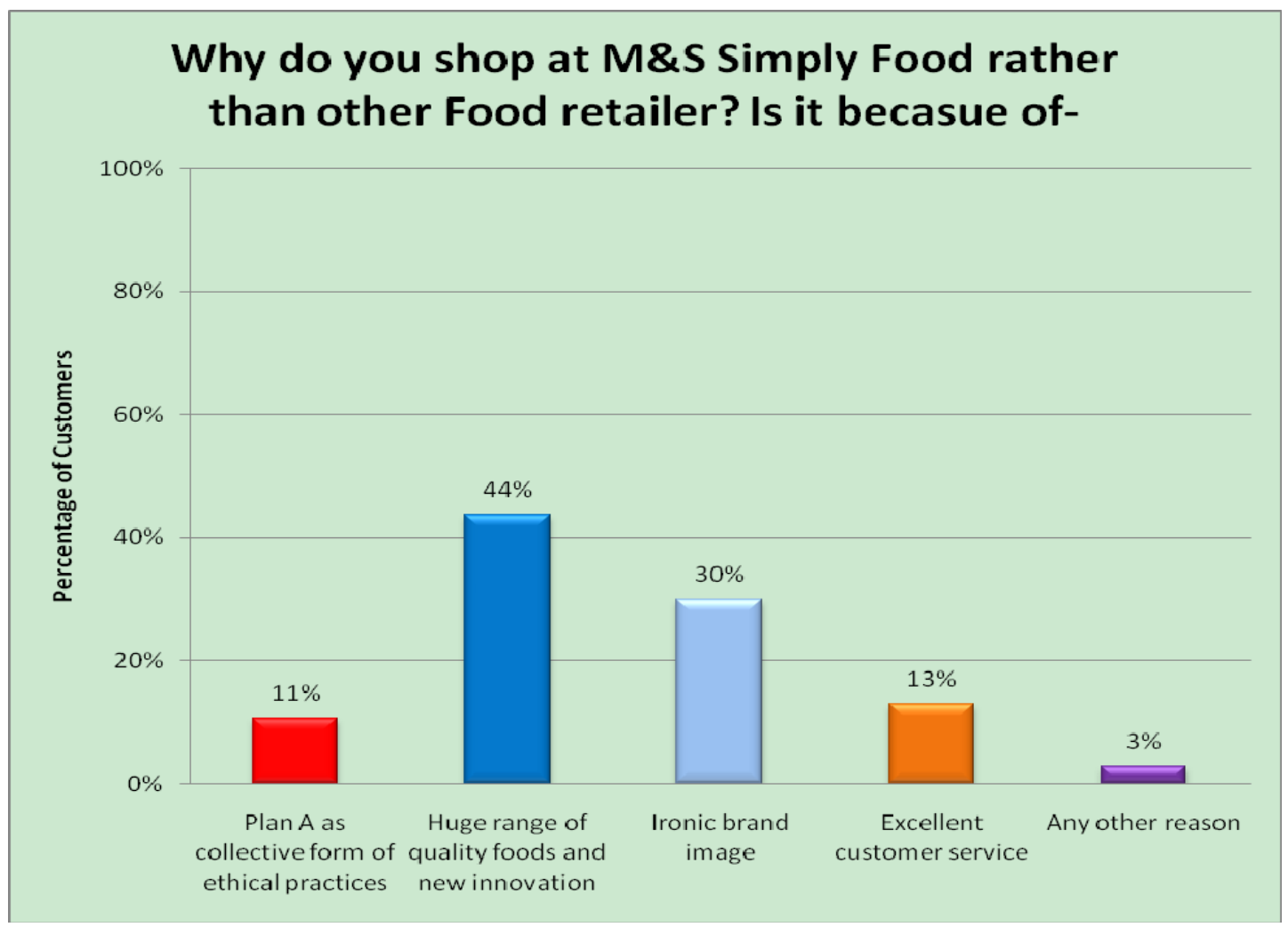

Figure 5. Question 2

\subsubsection{Data Interpretation and Findings: Question 2}

The chart shows that $11 \%$ of M\&S customers choose M\&S as because M\&S has plan A. $44 \%$ buy food from $M \& S$ because $M \& S$ has a huge range of foods and $M \& S$ keep innovating new range of foods. $30 \%$ of customers buy foods for the brand image of $\mathrm{M} \& \mathrm{~S}$, excellent customer service is another reason for $13 \%$ customers and $3 \%$ has different reasons that are not listed.

As per the interpretation of the data, it clearly shows that majority of the customers of M\&S buy foods because of huge range of foods in M\&S. Only a minority of customers consider Plan A as the determinants of being the customer of M\&S Simply Food.

Question 3: Do you know M\&S has Plan A with 100 commitments of ethical practices?

\begin{tabular}{|l|l|l|l|}
\hline Options & Total number of respondents & Reponses & Response in \% \\
\hline Know everything(1) & 385 & 121 & $31 \%$ \\
\hline Know a little bit(2) & 385 & 238 & $62 \%$ \\
\hline Just came to know from you(3) & 385 & 26 & $7 \%$ \\
\hline
\end{tabular}


Table 2. Question 3

\begin{tabular}{|l|l|l|l|l|}
\hline Minimum & Maximum & Median & Mean & Standard Deviation \\
1.00 & 3.00 & 2.00 & 1.79 & 0.66 \\
\hline
\end{tabular}

Table 3. Basic Statistics for Question 3

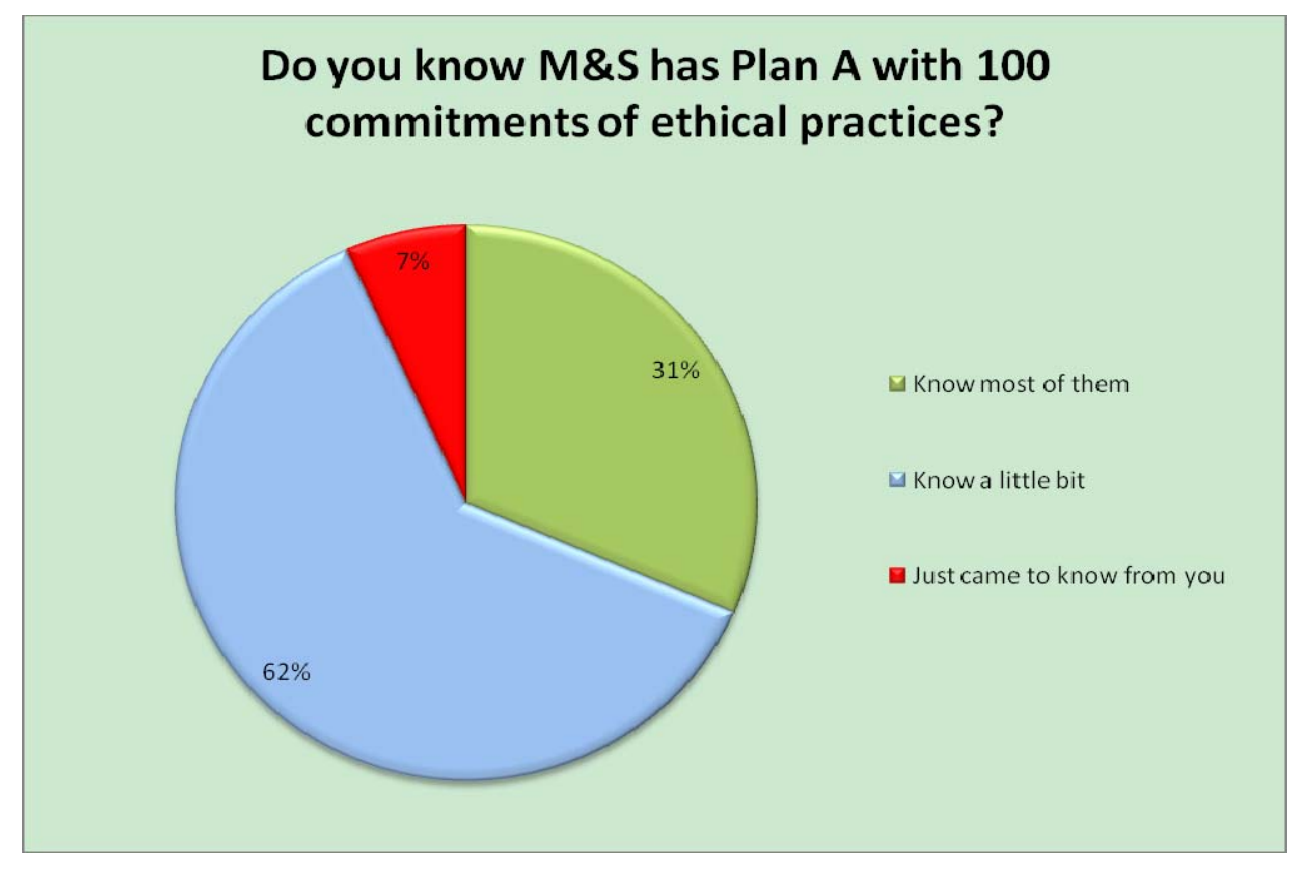

Figure 6. Question 3

\subsubsection{Data Interpretation and Findings: Question 3}

As per figure 3, it is very clear that majority of the customers of M\&S know a little bit about Plan A of M\&S and the percentage is $62 \%$. Only a minority of customers do not know anything about Plan A which is just 7\%. But good news for M\&S is-31\% of customers know most of them.

From the basic statistics table (Table 4), it is calculated that the standard deviation is 0.66 which interprets M\&S has no need to be worry letting customers know about Plan A. Mean is calculated as 1.79 which means majority of customers know about Plan A which is described from chart as well. 


\section{Macrothink}

Case Studies in Business and Management ISSN 2333-3324 2016, Vol. 3, No. 1

Question 4: Overall, how satisfied or dissatisfied are you with ethical practices of Marks and Spencer Simply Food?

\begin{tabular}{|l|l|l|l|}
\hline Options & Total number of respondents & Reponses & Responses in \% \\
\hline Very satisfied(1) & 385 & 120 & $31 \%$ \\
\hline Somewhat satisfied(2) & 385 & 182 & $47 \%$ \\
\hline Neither satisfied nor dissatisfied(3) & 385 & 76 & $20 \%$ \\
\hline Somewhat dissatisfied(4) & 385 & 5 & $1 \%$ \\
\hline Very dissatisfied(5) & 385 & 2 & $1 \%$ \\
\hline
\end{tabular}

Table 4. Question 4

\begin{tabular}{|l|l|l|l|l|}
\hline Minimum & Maximum & Median & Mean & Standard Deviation \\
1.00 & 5.00 & 2.00 & 1.93 & 0.78 \\
\hline
\end{tabular}

Table 5. Basic statistics for question 4

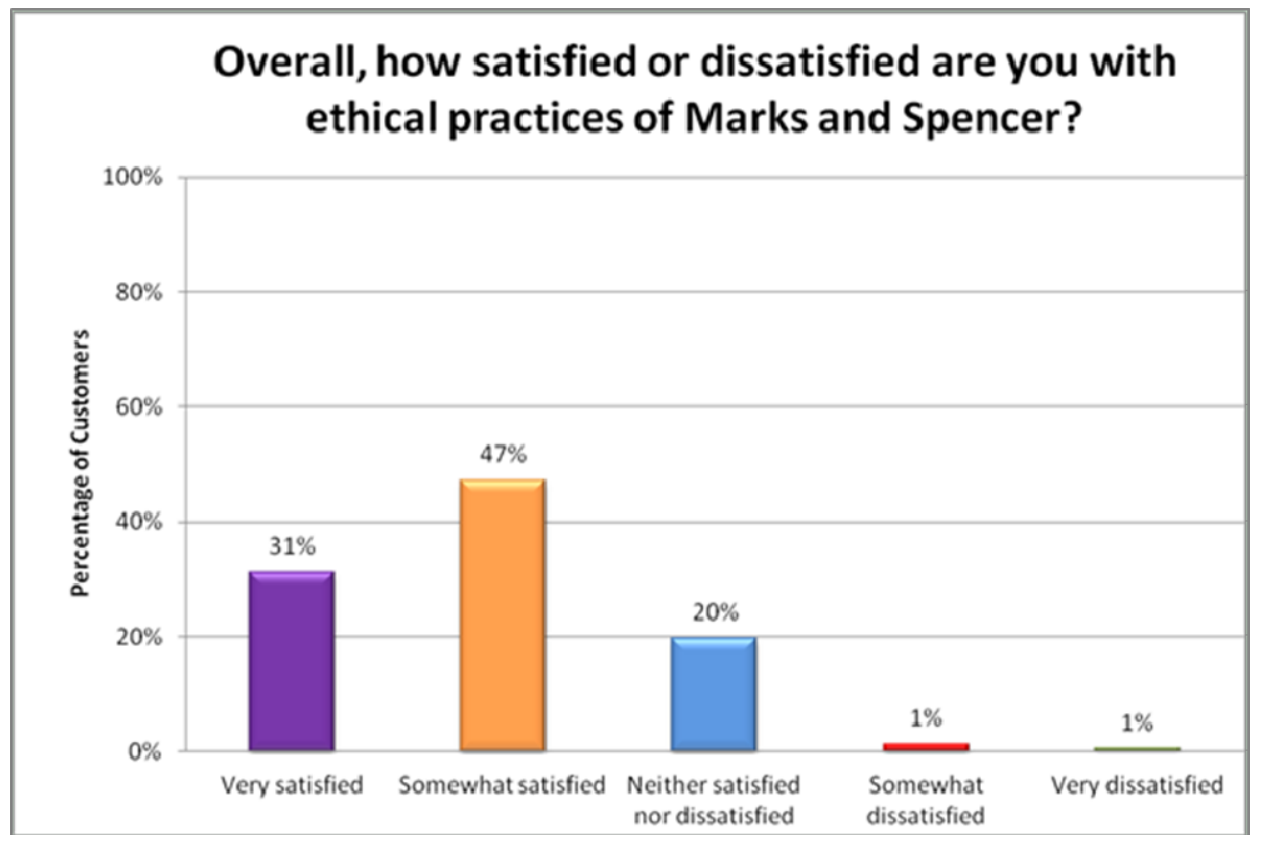

Figure 7. Question 4

\subsubsection{Data Interpretation and Findings: Question 4}

Majority of the employees' lies in option two, which denotes that $47 \%$ of customers are somewhat satisfied about Plan A of M\&S. 20\% remains neutral to show their position of satisfaction. But good news for M\&S is-31\% of customers are very satisfied about Plan A. Standard deviation is calculated 0.78 which denotes that M\&S has to show a little attention to make customers satisfied for Plan A. 


\section{Macrothink}

Case Studies in Business and Management

ISSN 2333-3324

2016, Vol. 3, No. 1

Question 5: How would you rate the quality of ethical practices of Marks and Spencer Simply Food?

\begin{tabular}{|l|l|l|l|}
\hline Options & Total number of respondents & Reponses & Responses in \% \\
\hline Very high quality(1) & 385 & 123 & $32 \%$ \\
\hline High quality(2) & 385 & 190 & $49 \%$ \\
\hline Neither high nor low quality(3) & 385 & 67 & $17 \%$ \\
\hline Low quality(4) & 385 & 2 & $1 \%$ \\
\hline Very low quality(5) & 385 & 3 & $1 \%$ \\
\hline
\end{tabular}

Table 6. Question 5

\begin{tabular}{|l|l|l|l|l|}
\hline Minimum & Maximum & Median & Mean & Standard Deviation \\
1.00 & 5.00 & 2.00 & 1.89 & 0.76 \\
\hline
\end{tabular}

Table 7. Basic Statistics for Question 5

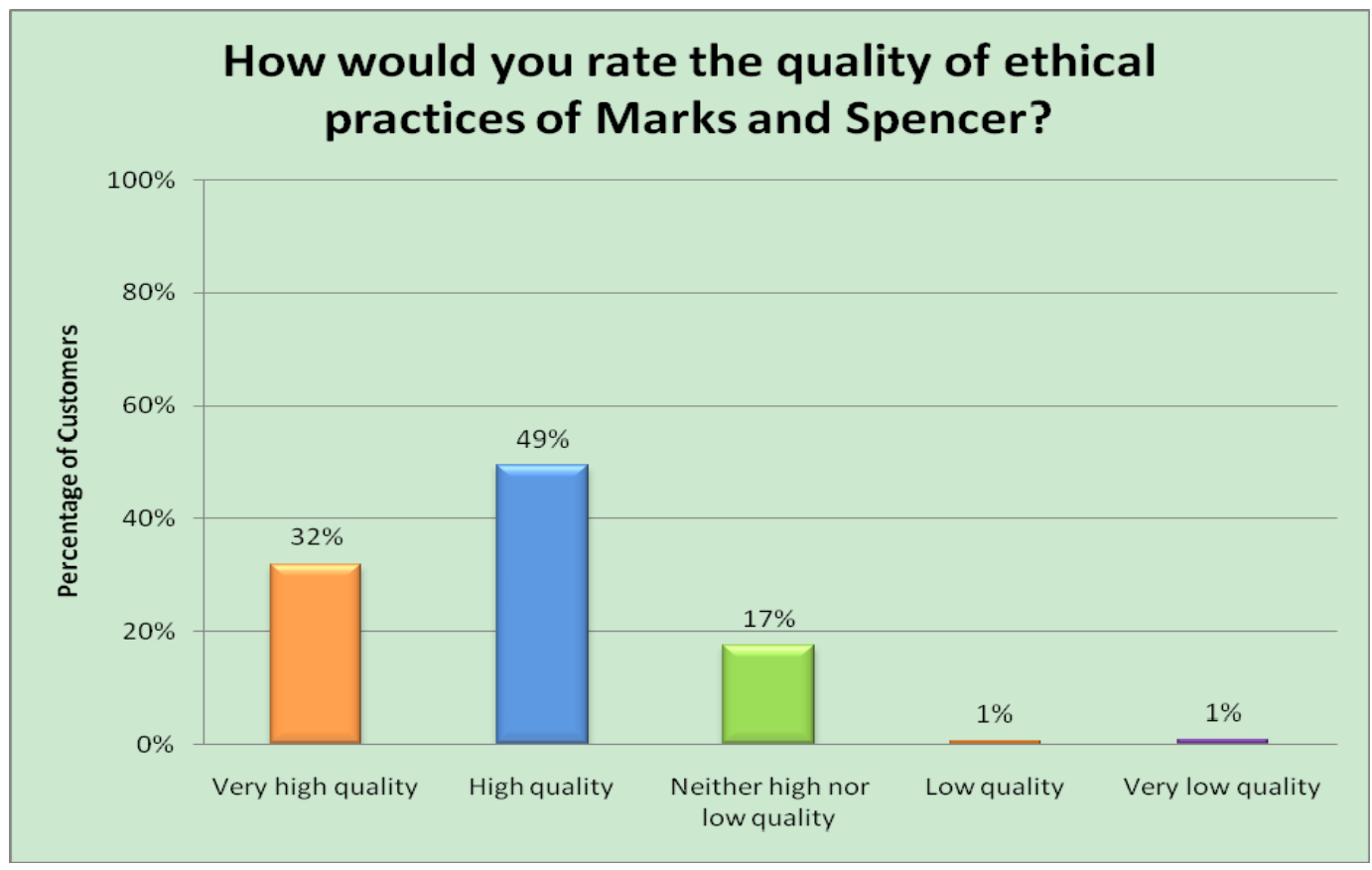

Figure 8. Question 5

\subsubsection{Data Interpretation and Findings: Question 5}

From the figure, it represents most of the customers think that the quality of Plan A is high and the percentage of those customers is $49 \%$. Moreover, $32 \%$ think M\&S is fulfilling its commitments of Plan A keeping them very high quality though $17 \%$ of customers stay neural to show their opinion. From the basic statistics table, the calculated mean is 1.89 which means it stays between the option one and two. Standard deviation of 0.76 shows that M\&S 


\section{Macrothink}

Case Studies in Business and Management

ISSN 2333-3324

2016, Vol. 3, No. 1

has not to be worry about increasing the qaulity of Plan A, just need to carry on fulfilling the rest of commintiments bering the same quality. This question is very much related to question 4 as the satisfaction of customers comes from the quality of service, in this case the quality of fulfilling the commitments and standard casues the satisfaction of concusmers.

Question 6: How long have you been a customer of Marks and Spencer?

\begin{tabular}{|l|l|l|l|}
\hline Options & Total number of respondents & Reponses & Responses in \% \\
\hline This is my first purchase(1) & 385 & 5 & $1 \%$ \\
\hline Less than six months(2) & 385 & 22 & $6 \%$ \\
\hline Six months to five years(3) & 385 & 36 & $9 \%$ \\
\hline Since launching of Plan A in 2007(4) & 385 & 48 & $12 \%$ \\
\hline before 2007(5) & 385 & 274 & $71 \%$ \\
\hline
\end{tabular}

Table 8. Question 6

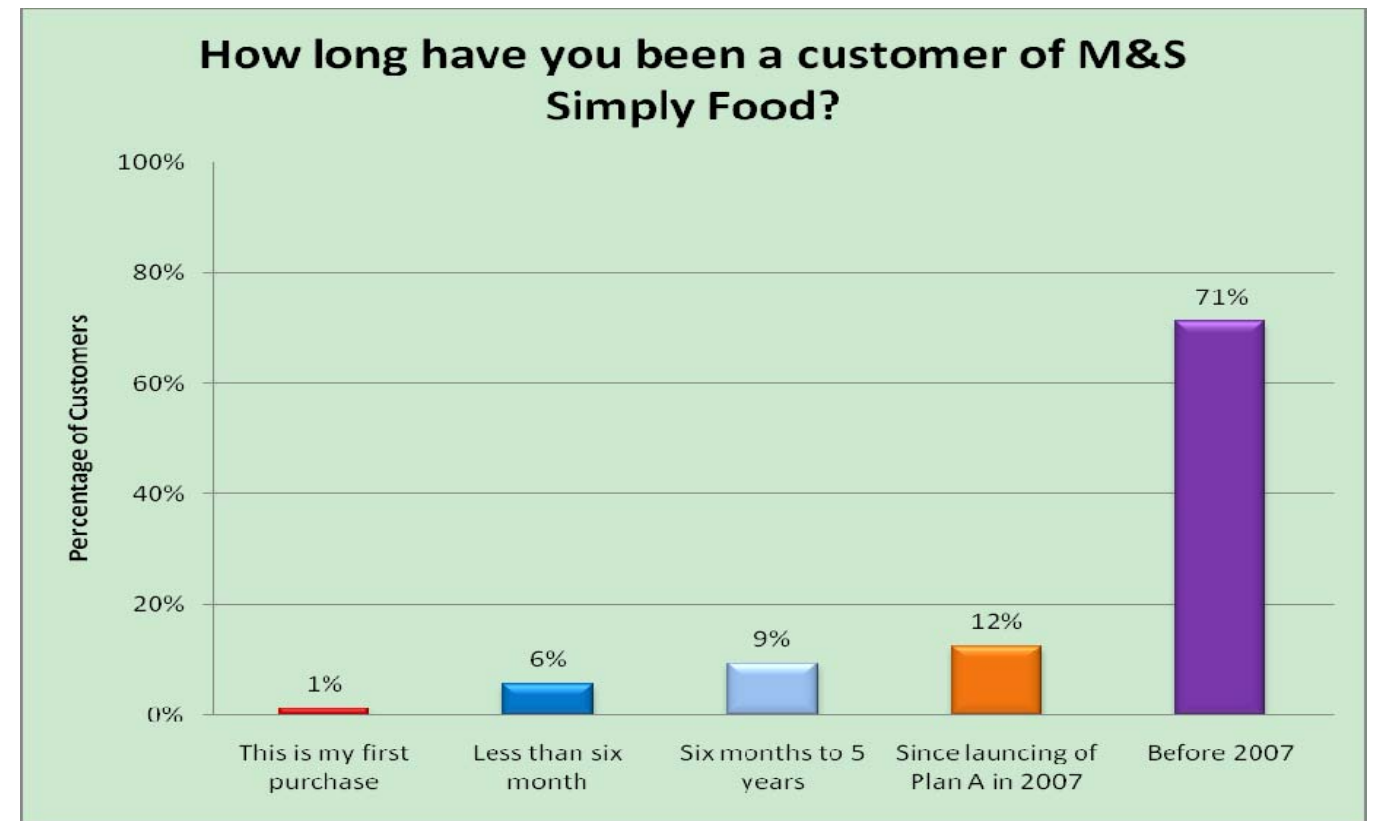

Figure 9. Question 6

\subsubsection{Data Interpretation and Findings: Question 6}

From the data presented at figure 6, it is very clear that $71 \%$ of customers are buying foods from M\&S Simply Food since 2007 and they can be defined as the most loyal customers of M\&S. However by launching plan A M\&S acquired an amount of customers and from them the percentage of customers who are still buying foods since 2007 are $12 \%$. This data can be co-related to question number 1 where it was found that $12 \%$ of customers are ethical 


\section{Macrothink}

Case Studies in Business and Management

ISSN 2333-3324

2016, Vol. 3, No. 1

customers. It also can be compared with question number two where it was found that $11 \%$ of customer buy foods from M\&S because of Plan A. Good news for M\&S is- it is still acquiring customers but not indentified any specific reason of acquisition at this point.

Question 7: How well do the ethical practices of M\&S motivate you to buy foods from M\&S Simply Food?

\begin{tabular}{|l|l|l|l|}
\hline Options & Total number of respondents & Reponses & Responses in \% \\
\hline Extremely well(1) & 385 & 29 & $8 \%$ \\
\hline Very well(2) & 385 & 16 & $4 \%$ \\
\hline Somewhat well(3) & 385 & 88 & $23 \%$ \\
\hline Not so well(4) & 385 & 91 & $24 \%$ \\
\hline Not at all well(5) & 385 & 161 & $42 \%$ \\
\hline
\end{tabular}

Table 9. Question 7

\begin{tabular}{|l|l|l|l|l|}
\hline Minimum & Maximum & Median & Mean & Standard Deviation \\
1.00 & 5.00 & 4.00 & 3.88 & 1.22 \\
\hline
\end{tabular}

Table 10. Basic Statistics for Question 7

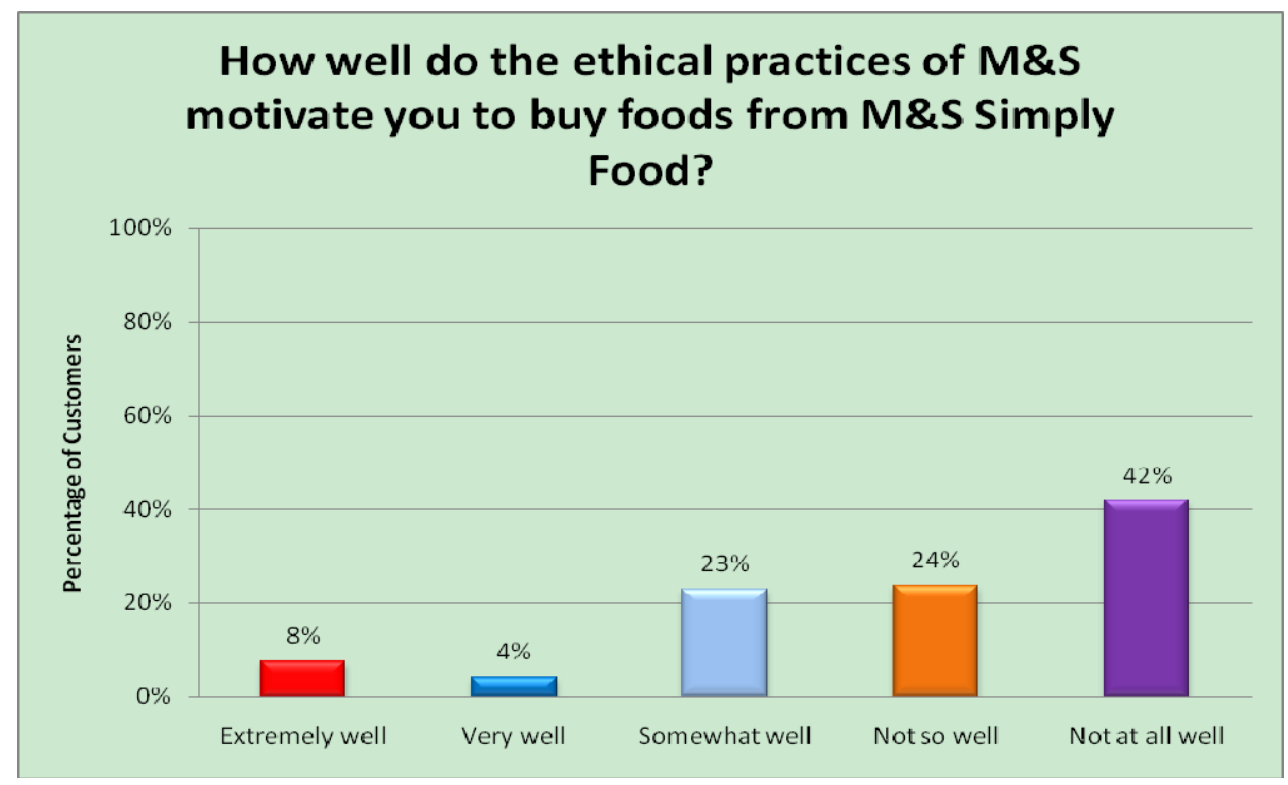

Figure 10. Question 7

\subsubsection{Data Interpretation and Findings: Question 7}

The figure has confirmed that, Plan A failed to motivate majority of customers. $42 \%$ of 


\section{Macrothink}

Case Studies in Business and Management

ISSN 2333-3324

2016, Vol. 3, No. 1

customers are not motivated at all by Plan A. Another $24 \%$ customers think Plan A motives them not so well. 23\% keep themselves neutral, as they could not decide the sources of motivation. 4\% customers think Plan A works very well as a motivator for them and another $8 \%$ feel it works extremely well. This has highlighted that option one and two has constructed $12 \%$ which may co-relates with the percentage of ethical customers of $12 \%$. Though most of the customers are satisfied about Plan A however when they buy foods from M\&S, they do not consider Plan A as a motivator. From the simple Statistics table, it shows that majority of customers' lies between options three and four which confirmed by the mean 3.88. The standard deviation of 1.22 denotes that M\&S has to think about why Plan A is not working as a motivator of purchasing behaviour for such amount of customers.

Question 8: How likely are you to purchase any of the foods again if Marks and Spencer would withdraw the commitments of ethical practices (Plan A)?

\begin{tabular}{|l|l|l|l|}
\hline Options & Total number of respondents & Reponses & Responses in \% \\
\hline Extremely likely(1) & 385 & 95 & $25 \%$ \\
\hline Very likely(2) & 385 & 175 & $45 \%$ \\
\hline Somewhat likely(3) & 385 & 76 & $20 \%$ \\
\hline Not so likely(4) & 385 & 25 & $6 \%$ \\
\hline Not at all likely(5) & 385 & 14 & $4 \%$ \\
\hline
\end{tabular}

Table 11. Question 8

\begin{tabular}{|l|l|l|l|l|}
\hline Minimum & Maximum & Median & Mean & Standard Deviation \\
1.00 & 5.00 & 2.00 & 2.19 & 1.00 \\
\hline
\end{tabular}

Table 12. Basic Statistics for Question 8

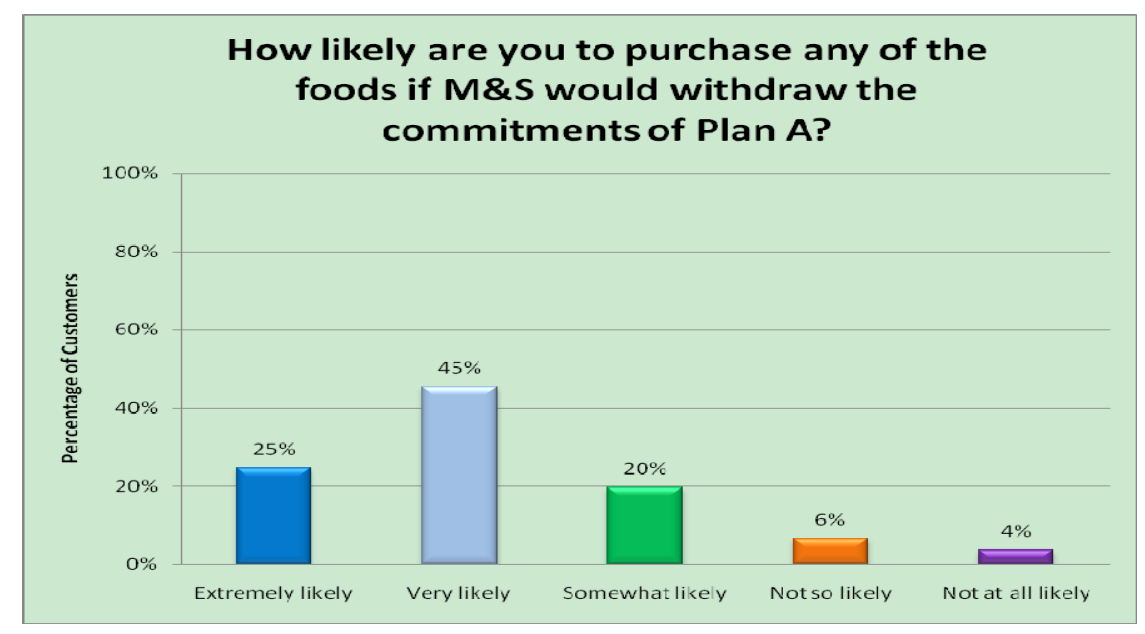

Figure 11. Question 8 


\subsubsection{Data Interpretation and Findings: Question 8}

From the chart, it is interpreted that withdrawing of Plan A impacts on a minority of customers from buying foods at M\&S and it is totalled just $10 \%$ which comes from option four and five. Another 20\% of customers stay neutral to express their position. However the majority of customers will continue to buy food from M\&S even M\&S would withdraw its Plan A. $45 \%$ of customers would most likely continue shopping and another $25 \%$ are extremely likely to keep shopping on M\&S. Standard deviation of 1.00 shows an expression that M\&S do not need to think about losing consumers as in total $70 \%$ of customers would keep buying foods if M\&S would withdraw its Plan A. On the other hand $10 \%$ of customer would leave M\&S from buying foods. This $10 \%$ can be compared with the percentage of ethical customers of $12 \%$. So it is clearly indentified that ethical practices of M\&S can dominate only $10 \%$ to $12 \%$ of customers' buying behaviour and loyalty issues. This $12 \%$ of customers can also be compared with option one and two from question seven.

\section{Linking the Objectives with Finding and Analyzed Data}

Linking with Objective 1: To find out the customers' understanding about ethical practices of Marks and Spencer Simply Food.

Customers' understanding of Plan A is excellent. As per the finding of question 3, it has became evident that majority (62\%) of the customers have some level of awareness and in total 93\% of customers knew about Plan A. As per the finding of question 4 and 5, majority of the customer believed that Plan based on very high quality ethical practices and because of that consumers are satisfied about the ethical practices of M\&S. Though very few percentage of consumers stays neutral to express their side however about $2 \%$ of customers are not satisfied.

\section{Linking with Objective 2: To find out the effectiveness of Plan A on consumers' purchasing decisions for Marks and Spencer Simply Food.}

From the interpretation and finding of question 1, question 2 and more specifically question 7 , it clearly denotes that ethical practices of Plan A are not affecting customers buying behaviour as majority of them think Plan A is not motivating them at all to buy foods from M\&S Simply Food.

Linking with Objective 3: To find out whether these practices make customers loyal to M\&S Simply Food.

In the case of Loyalty, only $12 \%$ of customer become loyal for Plan A that researcher found by interpreting the question 2 which shows 11\% of customers buy foods only for Plan A. From the question 6 , it also became very clear that $12 \%$ of customers became loyal to M\&S since 2007 when $M \& S$ launched plan A. It also further interpreted by the finding of question 8 as well that $10 \%$ of customers stop being loyal if M\&S would withdraw Plan A.

Linking with Objective 4: To understand if shoppers concisely take Plan A into account when deciding where to do their shopping. 
From the interpretation and finding of question 1 and 2, it is clearly identified that shopper do not concisely take plan A into account when buying foods from M\&S instead they consider the huge range of quality foods, ironic brand image, availability of store on location, and loyalty with retailer. They know everything about M\&S and they are satisfied about plan A however when it comes to decision making, they ignore Plan A and do not consider it as a priority.

\section{Linking with Objective 5: To establish if shoppers would shop elsewhere if M\&S withdrew its commitment of Plan A}

The finding of question 8 clearly established that majority of shoppers would not stop buying from M\&S Simply Food if M\&S would withdraw Plan A. In total percentage of such consumers are $70 \%$. Only $10 \%$ would stop buying which is a very minor to consider.

\subsection{Summary: Co-relate Objectives, Literature Reviews and Findings}

It was established on literature review about the reasons of integrating ethical practices with the core business strategy of Marks and Spencer. It was evident that the ultimate goal was to become number one sustainable retail business in the world. Sustainable retail business means to achieve sustainable competitive advantages over competitors. One way to achieve this is by acquiring and retaining high levels of customers. After measuring their positive financial outcome M\&S decided to keep moving with Plan A as embedded business strategy from 2007 and recently M\&S extended its number of commitments and extended the achievable year to 2020. However to evaluate one of the impacting areas of this strategy which is the relationship with customers and ethical practices, researcher performed a primary research, which was colleting primary data from customers. From the finding and analysis of data researcher found that the theory of meeting competitive advantages using Plan A is not meeting at all. Though Majority of the consumers believed that Plan A is a collection of very high quality ethical practices but on the case of buying decision and loyalty they do not care about ethical practices. However $71 \%$ consumers were found as loyal to M\&S for long time but the reason behind this loyalty is not Plan A. However minority of consumers are indentified as affected consumer by Plan A. This category of consumers lies between $10 \%$ and $12 \%$ only. Therefore the statement of Carrigan \& Attalla (2001, pp. 560-577) further proved that 'although consumers are more sophisticated today, this does not necessarily translate into behaviour that favours ethical companies over unethical ones'. Researcher's findings also proved the finding of Arnold's survey (2009) one more time that 'consumers believes so many things about ethical practices but they do not act according to their beliefs in the case of practices.

\section{Conclusion}

After the above discussion, it has became evident, the majority (Approximately 88\%) of the customers are well informed about plan A along with the commitments and they are satisfied about the quality of these ethical practices of Plan A. However they do not concisely take plan A when deciding where to buy foods. Moreover, Plan A does not motivate them at all to buy foods from M\&S. If M\&S would withdraw Plan A, majority of customers would continue buying foods from M\&S Simply Food. Therefore Plan neither works as the 
motivator of buying foods nor loyalty. However a small amount of consumer of M\&S Simply Food act just opposite comparing to majority consumers. Their percentage lies from $10 \%$ to $12 \%$. The business commentator and analyst define that type of customers as ethical customers. Therefore to summarise, Marks and Spencer need to further research on how to transform Plan A as a motivation factor for customers' purchasing decision and retaining loyalty.

\subsection{Recommendations}

As with the progression of the study researcher make some recommendations as follow:

\section{Marketing and Advertising:}

M\&S can advertise about Plan A. More concisely, the content of the advertising should focus on good impacts of Plan A on consumers which can motivate customers. It should campaign about how consumers can be benefited from Plan A. The benefits should include something monitory issues, health issues and social issues. This advertising could transform Plan A as motivation factor which would influence consumers' purchasing decision and assist M\&S to acquire, retain more customers.

\section{Increasing Customer Engagement and Investing on R\&D:}

M\&S should increase the engagement of customers within store and media about Plan A. M\&S can invest on RESEARCH to find out how can Plan A be a motivating factor for consumers' buying behaviour and loyalty issues.

\subsection{Further Scope of the Study}

For further research on the subject, researcher can take all the departments of Marks and Spencer, which can include clothing, home ware, M\&S Cafe, M\&S online shopping, and M\&S Simply Food. Increased valid data from all the department of M\&S will enhance further knowledge on the subject.

Further research can also focus on collecting qualitative data for better understanding of consumers' views. In addition future research will provide more thorough knowledge about ethical business strategy and its impacts on consumers' buying behaviour.

\section{References}

Arnold, C. (2009). Ethical Marketing and the New Consumer. Chichester: John Wiley and Sons Ltd.

Carrigan, M., \& Attalla, A. (2001). The Myth of Ethical Consumer-Do Ethics Matter in Purchase Behaviour? Journal of Consumer Marketing, 18(7), 560-577. http://dx.doi.org/10.1108/07363760110410263

Cryer, E. H., \& Ross, W. T. (1997). The Influence of Firm Behaviour on Purchase intention: Do Consumers Really Care about Business Ethics? Journal of Consumer Marketing, 14(6), 421-433. http://dx.doi.org/10.1108/07363769710185999 
Du Plessis, L. (2010). Customer Relationship Management and Its Influence on Customer Loyalty at Liberty Life in South Africa. Johannesburg: University of Johannesburg.

Eccles, R. G., \& Krzus, M. (2010). One Report: Integrated Reporting for a Sustainable Strategy. Hoboken: John Wiley \& Sons. [Online] Available: http://site.ebrary.com/lib/universityofessex/topChapters.action?p00=Sustainable_Strategy

Fan, Y. (2005). Ethical Branding and Corporate Reputation. Corporate Communication, 10(4), 241-350. http://dx.doi.org/10.1108/13563280510630133

Friedman, D. C., Brown, T. A., \& Taran, Z. (2007). Specialty Store Expertise as A Driver of Satisfaction and Share of Wallet. The international review of retail, distribution and consumer research, 21(4), 375-389. http://dx.doi.org/10.1080/09593969.2011.595497

Grayson, D. (2011). Embedding Corporate Responsibility and Sustainability Marks and Spencer. Journal of Management Development, 30(10), 1017-1026. http://dx.doi.org/10.1108/02621711111182510

Johnson, G., Whittington, R., Scholes, K., Angwin, D., \& Regner, P. (2014). Exploring Strategy. Harlow: Pearson Education Limited.

Kuusik, A. (2007). Affecting Customer Loyalty: Do Different Factors Have Various Influences In Different Loyalty Levels? Tartu: University of Tartu - Faculty of Economics \& Business Administration Working Paper Series.

Laczniak, G., \& Murphy, P. (1993). Ethical Marketing Decisions The Higher Road. Needham Heights: Allyn \& Bacon A division of Schuster Inc.

Marks and Spencer (2014). Annual Report and Financial Statements 2014. [Online] Available: http://planareport.marksandspencer.com/downloads/MS_AR2014_Annual_Report.pdf

Marks and Spencer (2014). Plan A Report 2014. [pdf] London: Marks and Spencer. [Online] Available:

http://planareport.marksandspencer.com/downloads/M\&S-PlanA-Performance-Summary-201 4.pdf

Marks and Spencer (n.d). About Plan A. [Online] Available: http://corporate.marksandspencer.com/plan-a/find-out-more/about-plan-a.

Marks and Spencer (n.d). About Us: Key Facts. [Online] Available: http://corporate.marksandspencer.com/aboutus/key-facts

Marks and Spencer (n.d). Plan A. [Online] Available: http://corporate.marksandspencer.com/plan-a

Rootman, C. (2006). The Influence of Customer Relationship Management on the Service Quality of Banks. Port Elizabeth: Nelson Mandela Metropolitan University.

Saunders, M., Lewis, P., \& Thornhill, A. (2012). Research Methods for Business Students. Harlow: Pearson Education Limited. 


\section{Macrothink}

Case Studies in Business and Management

ISSN 2333-3324

2016, Vol. 3, No. 1

Wall, S., Minocha, S., \& Rees, B. (2010). International Business. Harlow: Pearson Education Limited.

\section{Copyright Disclaimer}

Copyright for this article is retained by the author(s), with first publication rights granted to the journal.

This is an open-access article distributed under the terms and conditions of the Creative Commons Attribution license (http://creativecommons.org/licenses/by/3.0/). 